\title{
Structural Changes in the Maltese Economy
}

\author{
Dr. Aaron George Grech \\ Modelling and Research Department, Central Bank of Malta, Castille Place, Valletta, Malta \\ Email: grechga@centralbankmalta.org
}

\section{Doi:10.5901/mjss.2015.v6n5p423}

\begin{abstract}
Since the Great Recession, Malta has registered a more favourable economic performance than most other euro area states. It is difficult to reconcile this track record with the island's strong dependence on foreign trade. This article will argue that the enhanced performance of the Maltese economy could partly be explained by the pronounced structural changes that characterised it in the years preceding the crisis. This restructuring underpins a number of strong trends observed during recent years, such as the rise in labour participation, the improvement in the current account balance and the strong increase in unit labour costs. This is the first study for Malta since 2004 to utilise macroeconomic data going back further than 1995.
\end{abstract}

Keywords: Maltese economy, structural change, unit labour costs, small open economy, comparative economics, current account balance

\section{Introduction}

Since the global recession that took hold around the first decade of this century, Malta registered a more favourable economic performance than most of the other euro area states. It is difficult to reconcile Malta's relatively high rate of economic growth with the openness of a small economy facing a hostile external environment. However, this could partly be explained by the pronounced structural changes that occurred in the Maltese economy in the years preceding the crisis, which, although a continuation of the trends observed in the decades since Independence in the mid-1960s, gave a new impetus to the economy. In fact, they appear to have led to significant divergences from past macroeconomic behaviour.

The impact of structural changes on the Maltese economy is harder to discern due to the lack of consistent macroeconomic time series extending to the years before 1995, when the European System of Accounts 1995 was adopted by the National Statistics Office (see Grech \& Pace, 2004). Yet another major change in Malta's macroeconomic statistics was made in 2014, with the adoption of the European System of Accounts 2010 (see Pace Ross, Bonello \& Dimech, 2014). While recognising the fundamental differences between pre- and post-European System of Accounts data, this article utilises both to create a longer time series.

This is the first such study to be attempted for Malta as since the adoption of the European System of Accounts methodology in 2004, macroeconomic studies use 1995 as their starting point. It should be noted that this study will not undertake any econometric study of the macroeconomic time series, but will focus on a qualitative assessment of the longer time series for Malta. However the series are compared with those for the euro $\operatorname{area}^{1}$ to distinguish any different developments.

\section{Economic Growth and the Economy's Changing Structure}

In recent decades Malta's gross domestic product (GDP) has steadily risen and converged towards those of the advanced economies of the European Union. Thus, while in 1980 Malta's GDP per capita stood at just $48.0 \%$ of Germany's, by 2013 it had risen to $70.0 \%$.

Chart 1 shows that in the 1980-2000 period the trend in the business cycle in Malta has been similar to that of the euro area. However, growth in most years was higher in Malta than in the euro area. Real GDP grew at an average rate of $5.7 \%$ between 1988 and 1995 but slowed down in the second half of the 1990s, although at $4.7 \%$ was still higher than in the euro area. The first half of the 2000s marked a significant change of pace in Malta, as economic restructuring

\footnotetext{
1 Use of the term "euro area" in the 1980s and 1990s refers to the 18 European Union countries that made up the euro area as at the
} end of 2014. 
ahead of accession to the European Union in 2004 led to a marked slowdown in growth. While the liberalisation of markets and the removal of state aid and subsidies affected traditionally protected sectors, this period also saw the Maltese economy, in particular the electronics industry and the tourism sector, adversely hit by the substantial weakening of global demand, which had followed the bursting of the information technology stock bubble and the aftermath of the September 11 attacks on the United States.

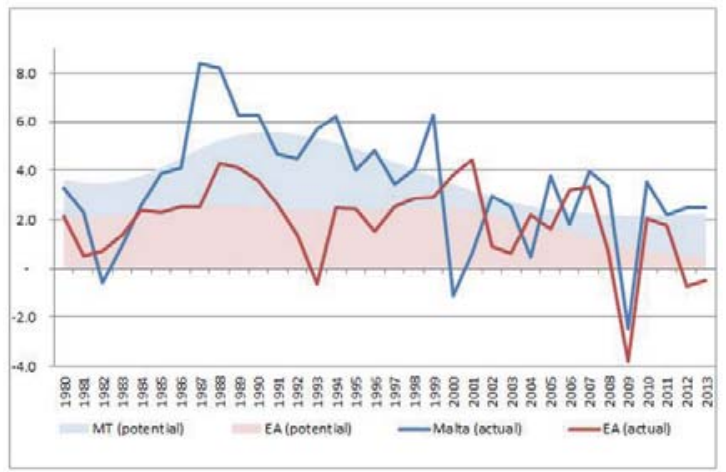

Chart 1. Real GDP Growth (Actual and Potential) - annual percentage changes

Despite the great recession, Malta's economic outturn remained relatively buoyant, and the gap between Maltese and euro area GDP growth rates started to diverge significantly. While in part this reflects the weak performance of the euro area as a whole, it provides evidence that Malta's potential output is picking up strongly and is no longer following the modest path observed since the early 1990s.

To understand the dynamics behind these developments, one can analyse the great ratios and net export shares of the Maltese economy and the euro area economy as a whole. These confirm that, as expected, the Maltese economy is rather more volatile than the euro area average (see Chart 2). In more detail, with a few exceptions, the sum of private and government consumption has been higher in Malta. In particular, during the 1990s, private consumption was buoyed by rising house prices and the easing of liquidity constraints following the liberalisation of the financial sector (see Cassar \& Cordina, 2001). However, in recent years the consumption to output ratio has declined and converged with the euro area average. On the other hand, while up to the 2000s the investment ratio in Malta had exceeded the euro area's, during the 2001-04 period it significantly declined. ${ }^{2}$ This continued after the great recession.

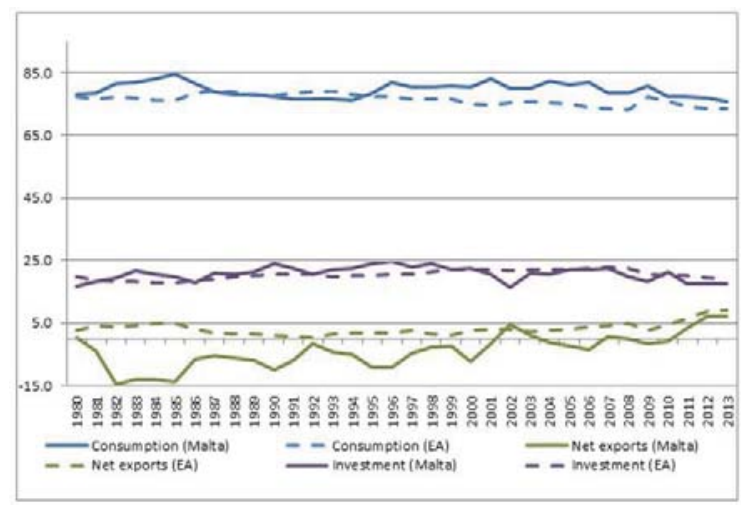

Chart 2. Great Ratios and Net Export Shares - \% of GDP

\footnotetext{
${ }^{2}$ Note, however, that the large decline reported for 2002 was a statistical effect of the national airline selling and leasing back its aircraft, rather than an actual decline in investment.
} 
The main medium-term difference between the Maltese and the euro area economies appears to be the development of the share of net exports of goods and services in GDP. While Malta had deficits of close to 15\% of GDP in the early 1980 s, the euro area has always been a net exporter. Malta's trade performance has steadily improved since the mid1980s, but the pace accelerated only since 2006. Thus, Malta has been a net exporter for the last four years, with a net export surplus as a percentage of GDP close to the euro area average.

Chart 3 helps explain why this turnaround occurred. In the early 1990s, similar to the euro area, the share of agricultural output in the Maltese economy stood at less than 3\% of total gross value added (GVA). By the early $21 \mathrm{st}$ century it had halved. The industrial sector in Malta was smaller in the 1990s than in the euro area, accounting for $28.4 \%$ of GVA against $30.4 \%$ for the latter. However, by the start of the 2000s, robust growth in Malta's industry, away from labour-intensive industries to more skilled and technologically-based manufacturing, contributed to a substantial narrowing of the gap. Subsequently, however, the growth rate of value added in the manufacturing sector started to decelerate: in fact, the value added in the period 2006-13 was just 7.1\% higher than in the 2000-05 period, as against a growth rate of $10.3 \%$ in the euro area in the same comparative periods. Reflecting this slower rate of growth, the share of industry in total value added declined to around 20\% during the period from 2006 to 2013, while it largely held up in the euro area, at around $25 \%$.

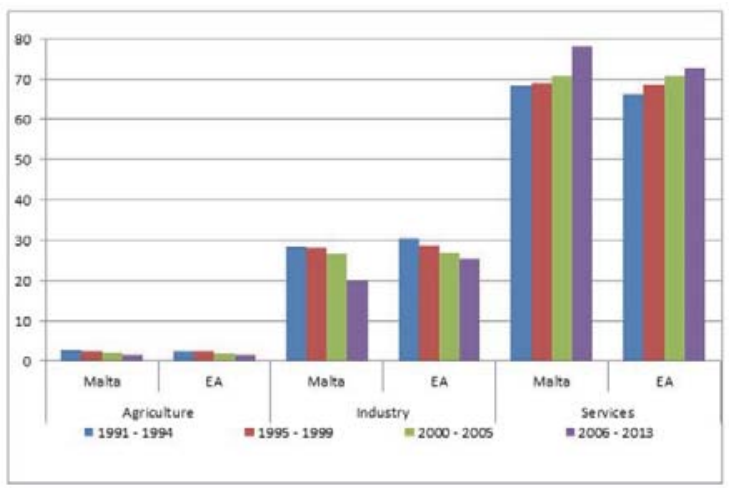

Chart 3. Sectorial Shares - \% of Total Gross Value Added

In contrast, growth in the services sector in Malta surged ahead. Liberalisation measures, the higher availability of better educated labour resources and a targeted strategy to attract foreign direct investment opened up new service sectors. Besides the traditional areas of tourism, education, health, retailing and banking activities, the services industry expanded to include higher value added activities generated by the financial services sector, specialised forms of tourism - like language schools and dive centres - maritime activity, professional services, back-office administration, information technology and gaming. Thus, over the 2006-13 period, the share of services in total output rose from $75.0 \%$ to $81.0 \%$ in 2013. In contrast, in 2013 the sector constituted less than 74\% of total activity in the euro area, just 2 percentage points higher than in 2006. While the latter had an external services surplus of $1.3 \%$ of GDP in 2013 , up from $0.5 \%$ in 2006 , Malta had an $18.8 \%$ surplus, up from $13.8 \%$ of GDP seven years earlier.

\section{The Broader Impact of these Structural Changes}

Chart 4 shows that after largely following a similar path to the euro area over the 25 years to 2013, Malta's Unit Labour Costs (ULC) have been rising at a much faster rate since 2006. ${ }^{3}$ Thus, in 2013 Malta's ULC index and the euro area's as a whole diverged by $17.0 \%$. This development appears to be inconsistent since the relative loss in competition has occurred exactly at the same time that Malta's external position has considerably strengthened, as a result becoming a net exporter in recent years.

The significant shift towards services may be a key explanation for this. For instance, while value added in

${ }^{3}$ ULCS measure the cost of labour compensation per unit of GVA produced. Typically, rising ULCs, particularly if increasing more than competitor countries, are seen as a worrying signal of a loss of competitiveness. 
manufacturing increased by just $9.0 \%$ between 2006 and 2013, employment in the sector fell by $14.0 \%$. In contrast, in two sub-sectors of services, namely, professional services and information \& communication services, GVA grew much more rapidly, rising by $75.1 \%$ between 2006 and 2013, while employment increased by $47.0 \%$. As a result, while GVA in these two sub-sectors was equivalent to just $75.0 \%$ of the manufacturing sector's in 2006 , by 2013 , these had a GVA which was equivalent to $115 \%$ of manufacturing. The service sector, by its very nature, tends to be characterised by lower labour productivity levels than in manufacturing. This reflects the fact that while manufacturing became increasingly less labour intensive and moved towards automation in production, services, despite more automation and computerisation, remain dependent on a higher level of labour input. The rapid expansion of services in Malta and their higher contribution to GDP therefore have tended to raise ULCs for the Maltese economy as a whole.

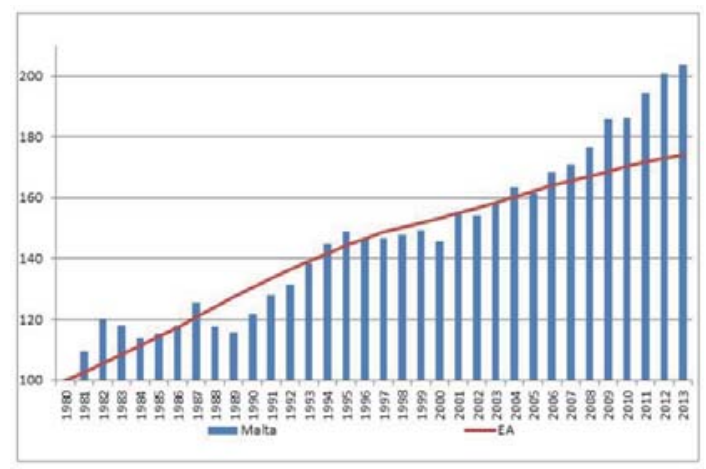

Chart 4. Unit Labour Costs $-1980=100$

An increase in a country's ULCs relative to those of its trading partner countries is likely to be reflected in a higher rate of inflation. However, as can be seen from Chart 5, in the case of Malta there is no evidence of this. In fact, in contrast with developments in ULCs vis-à-vis its euro area trading partners, retail price movements in Malta have been contained, and in fact the local rate of inflation has tended to converge with the euro area's over the past couple of years.

In the early 1980s, Malta's rate of inflation was higher than in the euro area, but wage and price controls, coupled with a sharp recession, resulted in a short bout of deflation. In the 1990s inflation picked up in the wake of a 10.0\% devaluation of the Maltese currency in 1992 that was triggered by the crisis in the European Exchange Rate Mechanism. The introduction of wage indexation at the same time may have resulted in the anchoring of inflation to a slightly higher rate than previously, though it is more likely that the higher inflation rate in the 1990s and early 2000s may have reflected the significant pace of economic growth and the associated pressures on wages. After a spike in the related price index, owing to a surge in international energy and food prices in 2008, inflation moderated in the subsequent years both in Malta and the euro area. Since 2010, there has been practically no divergence between Malta's retail price inflation and euro area inflation, as against a differential of 0.4 percentage point in the preceding decade.

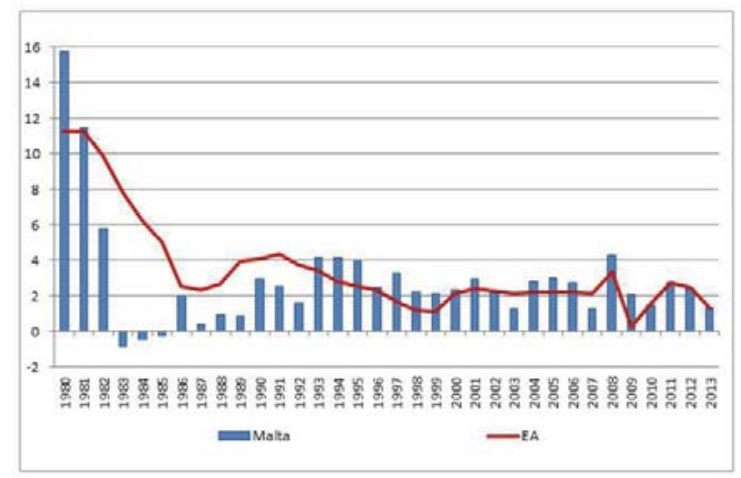

Chart 5. Inflation Rate - Moving Average \% Change 
Whereas inflation has converged to the euro area average, labour market developments in Malta have notably contrasted with those of the euro area (see Chart 6). Up to the mid-1980s, unemployment in Malta was particularly high and even exceeded the euro area's. The economic growth of the late 1980s, together with a sharp rise in public employment, helped reduce Malta's unemployment rate to well below the level in the euro area. The divergence continued to widen in the 1990s, but narrowed significantly in the early 2000s as the unemployment rate in Malta rose in response to the restructuring of the Maltese economy that was taking place ahead of EU accession. In the aftermath of the great recession, unemployment across most of the euro area increased sharply. In contrast, the Maltese labour market remained resilient, with the unemployment rate declining even though labour participation rates rose sharply (see Micallef, 2013). While government assistance to manufacturing and tourism helped to cushion the labour market from the effects of the recession, the diversification to service activities helped to strengthen the economy, notwithstanding the adverse economic and financial conditions surrounding it. The sectors that raised the demand for labour were the new service sectors, which, due to their very nature, were able to offer flexible conditions that attracted new entrants into the labour market. ${ }^{4}$ In fact, participation rates increased from $57.9 \%$ of the labour force in 2006 to $65.0 \%$ in 2013.

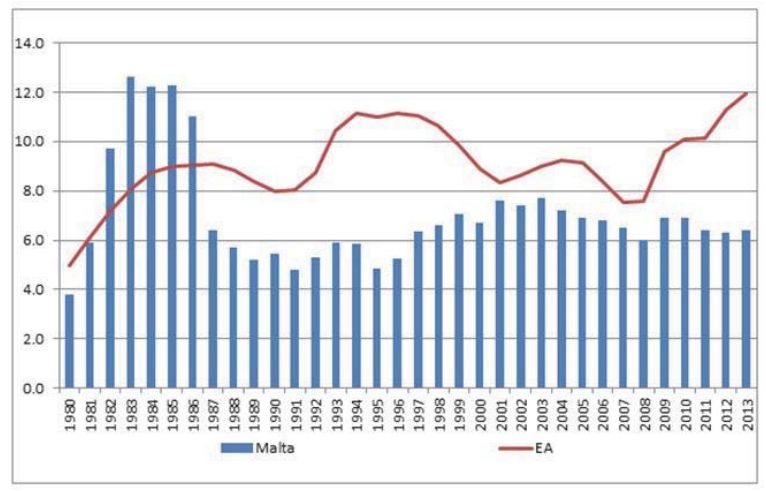

Chart 6. Unemployment Rate - \% of Labour Force

\section{Conclusion}

The structural changes in the Maltese economy are leading to a higher utilisation of labour resources and to a much improved position on the external account. Despite the investment ratio remaining below its historical average, potential output growth appears to be rising again and the inflation differential with the euro area has virtually disappeared, while the rate of economic growth has persistently exceeded the euro area's. For this benign scenario to continue, policymakers need to buttress their policies to improve labour skills and encourage more participation in the labour market, while supporting growth and competition across all sectors of the economy.

This article is a first attempt to study the long term evolution of the Maltese economy and compare it with developments in the euro area. It restricted itself to a qualitative assessment, and did not engage in econometric analysis of the results. In this regard, future studies could, for instance, attempt to test more rigorously the claim that the rise of the services sector was the main factor driving the deviation in unit labour costs. Similarly there is scope for seeking to understand how the rise in unit labour costs can be reconciled with the decline in inflationary pressures.

\section{Acknowledgements}

Any errors, as well as the views expressed in this article, are the author's sole responsibility. The data for the euro area used here are mostly from the Area Wide Model Database, http://www.eabcn.org/area-wide-model, the World Development Indicators Database, http://data.worldbank.org/data-catalog/worlddevelopment-indicators or the Eurostat website, http://ec.europa.eu/eurostat. Data for Malta pre-1995 can be found at http://www.centralbankmalta.org/real-

\footnotetext{
${ }^{4}$ For example, the number of persons employed in gambling and betting activities has been growing by an annual average rate of $14.7 \%$
} since 2009 
economy-indicators and in Grech (2003). Post-1995 data are Eurostat data.

\section{References}

Cassar, J. \& Cordina, G., (2001). "Consumption Expenditure in Malta: Behavioural Trends during the 1990s", Review, No. 23 Bank of Valletta, pp. 28-43.

Grech A. G. (2003), "Assessing Employment in Malta", Central Bank Working Paper 1.

Grech, A. G. \& Pace, C. (2004), "The Adoption of the European System of Accounts 1995 Framework in the National Accounts of Malta", Quarterly Review 2004:2, pp. 55-67.

Micallef, B. (2013) "Labour Market Resilience in Malta", Quarterly Review 2013:1, pp. 41-46.

Pace Ross M., Bonello J. \& Dimech V. (2014), "A New National Accounts Framework", Quarterly Review 2014:3, pp. 82-90. 